\title{
The Determinants of Phubbing Behaviour: a Millenials Perspective
}

\author{
Saurabh Verma, Rajender Kumar, Sunil Kumar Yadav
}

\begin{abstract}
In this contemporary world, where disruptive technologies are making their way to change the entire lifestyle of a mankind, smart phones have emerged to be a life changer. The smart phones which contain the features of pocket computers possess many properties which include camera, internet, online video streaming, game applications and social media networking. However, despite their obvious advantages in bringing people together virtually, smartphones on the contrary have pulled the people apart in reality. Further, the increased usage of smartphone has given birth to different addictions which create the tendencies for the basis of 'Phubbing'. The term 'Phubbing' is a combination of two words 'phone' and 'snubbing'. According to oxford dictionary, phubbing is "The practice of ignoring one's companion or companions in order to pay attention to one's phone or other mobile device" led to hamper the social relationships and romantic satisfaction, that ultimately resulting into a partner's depression and dissatisfaction with life. The use of phone during a conversation interfere the sense of connection to the other person, and obstructs the quality of the conversation. Therefore, a deep understanding and insight is required in this area so as to protect \& develop young brain socially and proactively. Keeping this in mind, a study was conducted among the millennial of Delhi (India) region so as to identify the key antecedents of Phubbing behavior. For the present study, 360 responses were collected through Purposive sampling technique. The study found that Watsapp addiction; Game addiction and Social Media addiction are the major determinants in affecting phubbing behavior of the millennial.
\end{abstract}

Keywords: Disruptive Technologies, Internet, Millennial, Phubbing

\section{INTRODUCTION}

The disruptive technologies always have two facets, on the one hand, it eases the way of performing a task by un-complicating the complications while on the other hand, it make us dependent on it, which further leads to its addiction. Similarly, the usage of computers is also having both the positive and negative aspects into it. The computer has caused negative consequences on human beings by offering them a huge range of activities, which includes the convenience of internet surfing and playing games. Further, it has been found that the computer is itself not a problem alone, but, the real problems arise because of the software installed in it. These

Revised Manuscript Received on October 31, 2019.

* Correspondence Author

Saurabh Verma, Department of Management Studies, National Institute of Technology, Silchar, India. Email: saurabhvermanitkkr@gmail.com

Rajender Kumar, Department of Business Administration National Institute of Technology Kurukshetra, India. Email: deswalrajinder15@gmail.com

Sunil Kumar Yadav*, Rukmini Devi Institute of Advanced Studies, Rohini, New Delhi, India. Email: sunilyadav29@gmail.com days' students stay online throughout the day and used to play games for a longer period of time. This is usually because of their urge to beat the competition virtually by moving towards the higher levels and attainment of high scores. Also, the high speed internet facilities with affordable unlimited plans further increased the binding of people towards these gadgets. The research of internet addiction begins with an electronic mail which was sent by Dr. Ivan Goldberg in the year 1996 to his peer groups in which he jokes about the usage of internet excessively by adjusting the managers of gambling disorder which can be seen in Diagnostics and Statistical Manual 5 (DSM-5). Excessive usage of computers led to a number of problems which have been arisen over a period of time but later, the focus was being shifted to a new platform which is one step ahead of computers now known as "smart phones". Smart phones can be defined as "a mobile phone which has a capability to perform many functions of computer, possess a touch screen, capability to get connected through internet, having a simple user interface and possess an operating system which can run downloaded applications". These smart phones contain the features of pocket computers and possess many properties such as camera, internet, writing programs, drawing programs, game applications, and social media networking. This disruptive technology has made the life of youth a bit easier but also has given birth to an alarming problem in the real social life of individuals i.e. PHUBBING.

The term 'Phubbing' is a combination of two words 'phone' and 'snubbing' which means addiction of mobile phones. The term was introduced for the first time by an advertisement agency McCann Group in their campaign in May, 2012. According to the oxford dictionary, Phubbing is "The practice of ignoring one's companion or companions in order to pay attention to one's phone or other mobile device". This act of snubbing someone in a social circle is found to be common now days. Although this type of behavior is commonly seen in all sectors of the society but, such behavior are pertinently visible among youth, specifically among the millennial or Generation Y consumers. A feeling of getting 'Phubbed' can be understood as an interruption in your conversation with someone, when he is in close proximity with his mobile phone instead of communicating with you and avoiding personal or social conversation. Also, phubbing behavior is aggravated because of the multifunctional capabilities of smart phone devices.

In recent times, Smartphone user can perform several functions simultaneously; due to easy access to internet and handy mobile applications and because of this, smartphones have become the companions of the user. 
Phubbing is caused because of the disturbance which originates from various forms of addictions of youth with their smart phone applications. If we try to carefully examine and analyze the issue than we may come to the conclusion that these addictions have a complex and multi-facet structure associated within them. It must be noted that effects of phubbing can be more upsetting and disturbing and is being more common than what it is been thought of. It is very difficult to assess that, whether mobile phone leads to internet addiction or vice a versa, obviously both trigger one another. The researcher reveals that, the mobile phone addiction increases with the increase in the time spent on internet surfing by the users. Sometimes, this addiction reaches to that epidemic level where we started using mobile phones, even, when they are prohibited. Further, it has been found that, mobile phone addiction may leads to anxiety, deficiency, disorder, stress and worries among its users when they are separated from their cellphones. Such incidents are increasing day by day which further suggests that phubbing has a significant association with the mobile phone addiction. Mobile phone addiction is caused due to several factors, one of which may be social media networking sites or apps. Social media includes content sharing, creating followers, consumer engagement through exchange of information and multi-media sharing which encourages the youth to stay online. Also, we cannot ignore the fact that social media is not 'the' single factor of mobile phone addiction rather messaging service apps such as 'Whatsapp' is among the topmost sites which fetches the attention of the millennial. Further, gaming addiction is another probable cause of distraction as youth consider this as a tool for relaxation. Gaming addiction includes playing video games, online games and other computer games, which have a same origin which affects the routine life of an individual. Therefore, the mobile phone addiction can be categorized on the basis of their usage, the dimensions may include 1) mobile phone addiction 2) internet usage addiction 3 ) social media addiction 4) gaming addiction and 5) Watsapp addiction. Based upon these arguments, the present study aimed to highlight the darker side of mobile phone usage. Further, the study will identify the key determinants of 'Phubbing' behavior among the millennial.

\section{LITERATURE REVIEW}

In the year 2010, Walsh et al. stated that the involvement of an individual with his mobile phone is an outcome of cognitive and behavioral issues. The cognitive part is associated with constant rational thinking about the cell phone [11]. The restlessness to know about the updates on mobile phone creates anxiety which results in continuous mobile phone checking. The behavioral component includes a close relation which is needed to be maintained with the mobile phone and to keep a constant check on the device [18]. Such a close association leads to mobile phone addiction. Therefore, the user is always concerned to know whether he has received any comment on his recent post or has received any message on instant messaging app such as Whatsapp [21]. Often, it is observed that people are conscious about the location of their smartphones and keep carry it along even when they are at home [16]. Further, mobile phone is not the problem which causes phubbing, but the applications installed in it are the factors which causes the addiction for mobile phone usage [8, 18]. Staying online and playing games for a longer period of time are some of the examples of the same. The study reveals that the frequency and the duration of using the internet have been increased at very high level whereas the usage of mobile phone has not been increased at the same pace.

It has been found that extreme internet addiction is erroneous for human beings. Sometimes, this addiction may lead them to the use of internet for the purpose of sex [12]. Youths use internet to view sexual content which affects negatively to their social life which results into personal isolation and other criminal offences. They sometimes symbolize internet with gambling and porn etc. not only this, several factors such as Cyber addiction, internet abuse, are some of the factors which are responsible for phubbing behavior among youths. While working on recording the patterns of mobile phone usage, Ericsson Mobility Report 2015 states that saturation of mobile phones has increased in our daily lives. One uses mobile phone at the time of waiting for train at the railway station, reaching home in the bus, in the classroom between the lectures and when not. Mobile phone is being used at the time of meeting friends, driving cars, on a walkway while crossing roads. Most of people use the mobile phone as the first thing when they wake up in the morning, as well as the last thing when they go to bed for sleep. The study revealed that $81 \%$ of the respondents keep their mobile phones adjacent to themselves for the whole day and enquire it 100 times a day on an average as if any update has taken place. Powered by the extensive interest in the social media applications, use of mobile phone becomes a tool of information, fun and high addiction. Similarly, another research stressed on the harmful significances of mobile phone intervention across various kinds of communication concepts, which includes personal conversation, interaction between parent and child, activities related to work management, and education practices.

There are several studies which support the mobile phone usage; they consider this as a tool to get updated and aware about our surroundings [23]. The study suggests that there is a positive association of mobile phones in developing expertise among professionals working in the sectors where technological updates are required on a regular basis [14]. In the competitive sector like healthcare and infrastructure, socialization and networking is essential to get connected with geographically distant professionals [22]. Several researchers studied about the relationship research where they found a strong association between phubbing and relationship status [17]. They examine the personal features and relationship sequence which lead to a satisfying and a happy relationship [7]. Moreover, they are looking for the reasons of failure of relationships and the remedies for the same. An illustration describes it in a manner where there is a positive and reliable correlation between mindfulness and relationship satisfaction. Another positive important trait which identified in the study is gratitude.

Self-gratitude and the gratitude perceived from the partner are highly associated with relationship satisfaction. Similarly, a study discuss the detoxication of digital time which shows the relation of between the misuse of mobile technology and phubbing [20]. With the advancement in field of technology, students have massive collection of e-communication tools at the tips of their fingers [5].

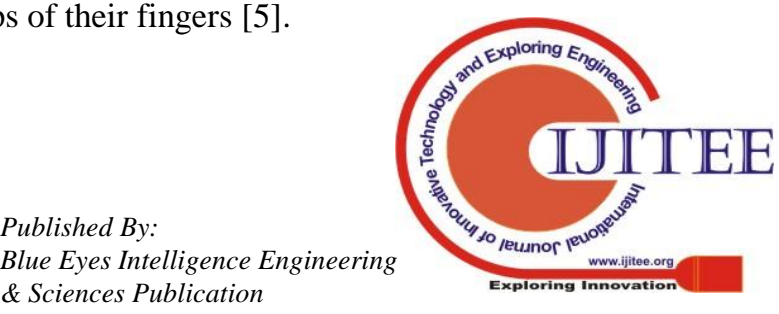


The research has found that $100 \%$ of students are having mobile phones and they bring the device in their classrooms. A very less number of students use their mobile phones for the purpose of learning, like to look for the information of their lesson, images of the information, whereas the majority of the students use the device for their personal use during the classroom. It hinders the learning of the students and this happens during the examination which is considered as illegal. The result reveals that the pattern of \% in the gender will depict the intention of students. It is observed that males are calmer than females and females are more sensitive in case of disturbing their classmates [4]. There is a huge impact of the size of the classroom. It is found that there are huge implications on the mental health with the excessive use of internet surfing, texting, gaming, making calls, social networking and emailing [9]. A smart phone allows performing all these activities anywhere and anytime. A high significant association is observed between smart phone involvement and level of stress and depression but not with the level of anxiety and concern. The performance of student during the classroom is affected when their mobile phone rings. The ringing of mobile phone is a distraction, though students cannot converse with the caller. But, they can communicate by texting them on mobile phone silently which allows wide exchange of conversation during the lectures which will obviously disturb the performance of student [3]. Discipline in the classroom is an important part in learning and it becomes difficult for the teacher to struggle with the negative effects of mobile phone on students so that they can easily focus on learning. Students have also found innovative ways to use cellphones during the exams by retrieving information and taking pictures of the exam. The faculty perceives that the use of cell phone is very different in classroom, where faculty wish to strictly ban them and while others feel that the guidelines for using cell phone are unnecessary [6]. Many institutions have guidelines which restricts the students to carry and use mobile phone at the time of lectures, whereas some institutions are not so restrictive [2]. A study made by association of national education shows that $85 \%$ of faculty in US agrees that professors must include a policy regarding the use of mobile phone in class. In the modern era, the classrooms of university have two instructions: the chalkboard and the projector. All the technological items are controlled and utilized by the faculty only [15]. Maybe the most challenging, interesting and controversial technology which is to be introduced is not coming from the faculty but from the students who are bringing electronic devices into the classroom [1]. In the initial days, an annoying ringing bell of the mobile phone announces its presence and others look around to know to whom it belongs. This becomes difficult for the faculty to maintain the attention of the classroom. Later on, this ringing bell changes into the notes of song, then vibrations and lastly to text messages. Every single call becomes a matter of distraction for one or the other. Now, with the access to the internet, mobile phone helps to browse on many websites like Facebook and also in checking mails and text messages. Also, the association between the texting of student with literacy level and reports that there is a positive relationship [19]. It is identified that texting affects the literacy level of student negatively. Texting at the time of lectures affects the ability to self-regulate their attention in the learning. Students are habitual in texting and studying simultaneously during the classroom.

\section{OBJECTIVE OF THE STUDY}

The main objective of the present study is to analyze the key determinants of Phubbing behavior among the millennial.

\section{RESEARCH METHODOLOGY}

\section{A. Sample Area}

The present study has been conducted on the mobile phone users of Delhi (NCR), India. Further, the study focusses only on the millennial or Generation $\mathrm{Y}$ consumers who falls between the age bracket of 22-37, or born between 1981 and at the end of 1996 [10]. The reason behind the selection of millennial is that they are the chief wage earners in India with a $47 \%$ share in the working age population [13]. Also, the millennial consumers are much more segmented as an audience alleviated by the fast growing telecommunication sector including TV channels, web series, satellite radio and e-zins etc.

\section{B. Data Collection}

The study is based on both primary and secondary data. The required primary data were collected through self-administered questionnaire. Personal interviews were conducted among 360 respondents. The required secondary data were collected from the articles/papers published in various journals/blogs and other electronic.

\section{Sample Design and Sample Size}

The respondents were selected through Purposive Sampling (Non-Probability sampling). The reason behind the choice of purposive sampling is because, in this sampling technique, a researcher can focus on particular characteristics of a sample population that are of his interest and can draw relevant inferences. To analyze the data, descriptive research design based on the quantitative methods has been used. A sample size of 360 respondents was selected for administering the questionnaire. The formulae used for calculation of sample size for infinite population is being adopted from Cochran (1977) which is as follows:

\section{$n_{0}=z^{2} p q / e^{2}$}

$\mathrm{n}_{0}=$ Sample Size

$\mathrm{z}=$ critical value of desired confidence level (1.96)

$\mathrm{p}=$ the population proportion $(.05)$

$\mathrm{q}=1-\mathrm{p}(0.5)$

$\mathrm{e}=$ desired level of precision (.08)

Assuming the maximum variability, equal to $50 \%(\mathrm{p}=.05)$ with taking $95 \%$ confidence level with $\pm 8 \%$ precision, the required sample size will be as follows:

$\mathrm{n}_{0}=(1.96)^{2}(.05)(.05) /(.08)^{2}=360$

\section{Research Instrument \& Reliability}

The questionnaire formulated for the present study comprises of scale items related to dependent and independent variables and the respondents were then asked to give their responses on a five-point Likert scale ranging from " $1=$ strongly disagree to $5=$ strongly agree". All these scale items were adopted from the study conducted by Karadag et al., 2015 [11]. 
The Determinants of Phubbing Behaviour: a Millenials Perspective

However, due to cultural and technological disparities, the scales were being modified as per the Indian scenario. To check the reliability of the different constructs, Inter Consistency Reliability test (ICR) has been used. The reliability coefficient Cronbach's alpha values of the constructs have been calculated. Cronbach's alpha value of more than 0.70 or above is acceptable [19]. Table 1 depicts the source of scales items and the results of reliability analysis.

TABLE I. RELIABILITY ANALYSIS SUMMARY

\begin{tabular}{|l|l|}
\hline Scales & Cronbach's alpha \\
\hline Cell phone addiction & .971 \\
\hline Web Browsing addiction & .925 \\
\hline $\begin{array}{l}\text { Whatsapp/Messaging apps } \\
\text { addiction }\end{array}$ & .963 \\
\hline $\begin{array}{l}\text { Social networking site } \\
\text { addiction }\end{array}$ & .961 \\
\hline Online Gaming addiction & .984 \\
\hline Phubbing & .892 \\
\hline
\end{tabular}

The validity of the various scales was tested to ensure that the research instrument is measuring what it is designed to measure. To check the content validity and face validity, experts from the similar domain were asked to compare and evaluate the items included in the questionnaire with the research objective. Further, an Exploratory Factor Analysis was being conducted to assign the items to the factors. Table II depicts the rotated component matrix for the different factors.

\begin{tabular}{|c|c|c|c|c|c|c|}
\hline & ABLE & & ATEI & UN & NT & \\
\hline & Comp & & & & & \\
\hline & 1 & 2 & 3 & 4 & 5 & 6 \\
\hline CPA1 & & .789 & & & & \\
\hline CPA2 & & .766 & & & & \\
\hline CPA3 & & .781 & & & & \\
\hline CPA4 & & .845 & & & & \\
\hline CPA5 & & .817 & & & & \\
\hline CPA6 & & .772 & & & & \\
\hline CPA7 & & .828 & & & & \\
\hline CPA8 & & .760 & & & & \\
\hline WBA1 & & & & & & .624 \\
\hline WBA2 & & & & & & .574 \\
\hline WBA3 & & & & & & .536 \\
\hline WBA4 & & & & & & .605 \\
\hline WBA5 & & & & & & .662 \\
\hline SNAA1 & .657 & & & & & \\
\hline SNAA2 & .637 & & & & & \\
\hline SNAA3 & .697 & & & & & \\
\hline SNAA4 & .790 & & & & & \\
\hline SNAA5 & .812 & & & & & \\
\hline SNAA6 & .765 & & & & & \\
\hline SNAA7 & .708 & & & & & \\
\hline SNAA8 & .710 & & & & & \\
\hline SNAA9 & 809 & & & & & \\
\hline SNAA10 & .719 & & & & & \\
\hline OGA1 & & & .915 & & & \\
\hline
\end{tabular}

\begin{tabular}{|l|l|l|l|l|l|l|}
\hline OGA2 & & & .881 & & & \\
\hline OGA3 & & & .931 & & & \\
\hline OGA4 & & & .927 & & & \\
\hline OGA5 & & & .924 & & & \\
\hline OGA6 & & & .924 & & & \\
\hline WA1 & & & & & .804 & \\
\hline WA2 & & & & & .832 & \\
\hline WA3 & & & & & .667 & \\
\hline WA4 & & & & & .692 & \\
\hline WA5 & & & & & .688 & \\
\hline WA6 & & & & & .793 & \\
\hline PHUB1 & & & & .659 & & \\
\hline PHUB2 & & & & .710 & & \\
\hline PHUB3 & & & & .676 & & \\
\hline PHUB4 & & & & .728 & & \\
\hline PHUB5 & & & & .663 & & \\
\hline PHUB6 & & & & .623 & & \\
\hline PHUB7 & & & .586 & & \\
\hline PHUB8 & & & .702 & & \\
\hline $\begin{array}{l}\text { Extraction Method: Principal Component Analysis. } \\
\text { Rotation Method: Varimax with Kaiser Normalization. } \\
\text { a. Rotation converged in 6 iterations. }\end{array}$ & & \\
\hline
\end{tabular}

\section{E. Data Analysis}

The collected data were analyzed using various mathematical and statistical tools. The hypotheses formulated were tested using stepwise regression. The IBM SPSS version 18.0 (International Business machines- Statistical Package for Social Sciences) was being used for the data analysis.

\section{RESULTS AND DISCUSSIONS}

A stepwise regression was being conducted to analyze the key determinants affecting Phubbing behavior of Generation Y. In stepwise regression method, at each step, statistically significant independent variables, in order of their importance are selected. Further, it looks for the independent variable that most correlates with the dependent variables at different steps. It continues until all the significant variables are entered into the equation and thus the final step represents the best regression model. The independent variables taken for the analysis were Cell phone addiction, Web Browsing addiction, Whatsapp/Messaging apps addiction, Social networking apps addiction and Online Gaming addiction whereas the dependent variable was phubbing. Table III depicts the mean and standard deviation descriptive scores for the dependent and independent variables.

TABLE III. DESCRIPTIVE STATISTICS

\begin{tabular}{|l|l|l|l|}
\hline & Mean & Std. Deviation & N \\
\hline Phubbing & 4.2425 & .88474 & 360 \\
\hline Web Browsing addiction & 4.2838 & .77887 & 360 \\
\hline Watsapp/Messaging apps addiction & 4.1060 & .83483 & 360 \\
\hline Social networking apps addiction & 4.2040 & .83084 & 360 \\
\hline Online Gaming addiction & 3.4750 & .71775 & 360 \\
\hline Cell phone addiction & 4.2450 & .97398 & 360 \\
\hline
\end{tabular}


The results of the stepwise regression model are depicted in Table IV. It illustrates that among the five determinants; Watsapp/Messaging apps addiction, Online Gaming addiction and Social networking apps addiction are found to having a statistically significant relationship with the phubbing behavior. Further, the multiple correlation coefficient is $\mathrm{R}=.882$, which signifies strong correlation. In terms of variability, the value of $\mathrm{R}^{2}=.790$. The value of adjusted $R^{2}$ is analyzed as it gives the actual percentage of variation explained by only those independent variables that in reality affects the dependent variable. The value of adjusted $\mathrm{R}^{2}$ for the present regression model is 0.782 which indicates that $78.28 \%$ of the variations in phubbing behavior of generation $\mathrm{Y}$ can be explained by the five explanatory variables (Table IV).

The value of Durbin Watson statistic for the present model is 2.153 which is closer to 2 which suggest that no autocorrelation exists in the regression model (Durbin, 1950). The ANOVA results are being illustrated in Table V.

TABLE IV. MODEL SUMMARY

\begin{tabular}{|c|c|c|c|c|c|}
\hline Model & $\mathbf{R}$ & R Square & $\begin{array}{l}\text { Adjusted R } \\
\text { Square }\end{array}$ & $\begin{array}{l}\text { Std. Error } \\
\text { of the Estimate }\end{array}$ & $\begin{array}{l}\text { Durbin } \\
\text {-Watso } \\
\text { n }\end{array}$ \\
\hline 1 & $.817^{\mathrm{a}}$ & .668 & .665 & .51216 & \multirow{5}{*}{2.153} \\
\hline 2 & $.854^{\mathrm{b}}$ & .729 & .723 & .46562 & \\
\hline 3 & $.872^{\mathrm{c}}$ & .761 & .753 & .43953 & \\
\hline 4 & $.883^{\mathrm{d}}$ & .778 & .770 & .42937 & \\
\hline 5 & $.882^{\mathrm{e}}$ & .790 & .782 & .42292 & \\
\hline
\end{tabular}

a. Predictors: (Constant), Watsapp/messaging apps addiction, Online gaming addiction, Social networking apps addiction

b. Dependent Variable: Phubbing

TABLE V. ANOVA

\begin{tabular}{|c|l|l|l|l|l|l|}
\hline \multicolumn{2}{|l|}{ Model } & $\begin{array}{l}\text { Sum of } \\
\text { Squares }\end{array}$ & df & Mean Square & F & Sig. \\
\hline \multirow{2}{*}{1} & Regression & 60.324 & 3 & 20.108 & 112.422 & .000 \\
\cline { 2 - 7 } & Residual & 17.171 & 356 & .179 & & \\
\cline { 2 - 7 } & Total & 77.494 & 359 & & & \\
\hline
\end{tabular}

a. Predictors: (Constant), Watsapp/messaging apps addiction, Social networking apps addiction, Online gaming addiction

b. Dependent Variable: Phubbing

It shows that the value of $\mathrm{R}^{2}$ is found to be significant as statistics for $F(3,356)=112.422, p<.005$. In addition to this, $\beta$ values have been calculated to indicate that to what degree each predictor affects the regression model. The final regression model as depicted in Table VI indicates that Watsapp/Messaging addiction $(p<.005, \beta=.419)$ has emerged to be the most statistically significant determinant in predicting phubbing behavior followed by Online gaming addiction $(\mathrm{p}<.005, \beta=.352)$ and Social networking addiction $(\mathrm{p}<.005, \beta=.224)$. VIFs (Variable Inflation factors) are being calculated in Table VI which depicts that multi-collinearity is not a problem for the regression model as the values are well below 10 .
TABLE VI. COEFFICIENTS

\begin{tabular}{|c|c|c|c|c|c|c|c|}
\hline \multirow[b]{2}{*}{ Model } & \multicolumn{2}{|c|}{$\begin{array}{l}\text { Unstandardize } \\
\text { d Coefficients }\end{array}$} & \multirow{2}{*}{$\begin{array}{c}\text { Standardized } \\
\text { Coefficients } \\
\text { Beta }\end{array}$} & \multirow[b]{2}{*}{$\mathbf{T}$} & \multirow[b]{2}{*}{ Sig. } & \multicolumn{2}{|c|}{$\begin{array}{l}\text { Collinearity } \\
\text { Statistics }\end{array}$} \\
\hline & B & $\begin{array}{l}\text { Std. } \\
\text { Error }\end{array}$ & & & & $\begin{array}{l}\text { Tolera } \\
\text { nce }\end{array}$ & VIF \\
\hline$($ Constant $)$ & .008 & .249 & & .033 & .000 & & \\
\hline $\begin{array}{l}\text { Watsapp } \\
\text { addiction }\end{array}$ & .380 & .065 & .419 & 5.875 & .000 & .455 & $\begin{array}{l}1.20 \\
0\end{array}$ \\
\hline $\begin{array}{l}\text { Online } \\
\text { Gaming } \\
\text { addiction }\end{array}$ & .254 & .076 & .352 & 4.230 & .001 & .512 & $\begin{array}{l}1.95 \\
3\end{array}$ \\
\hline $\begin{array}{l}\text { Social } \\
\text { networkin } \\
\mathrm{g} \\
\text { addiction }\end{array}$ & .373 & .088 & .224 & 3.329 & .000 & .333 & $\begin{array}{l}1.00 \\
2\end{array}$ \\
\hline
\end{tabular}

a. Dependent Variable: Phubbing

TABLE VII. EXCLUDED VARIABLES

\begin{tabular}{|c|l|l|l|l|l|l|}
\hline Model & Beta In & t & Sig. & \multicolumn{2}{|l|}{$\begin{array}{l}\text { Collinearity } \\
\text { Correlation }\end{array}$} & \multicolumn{2}{|l|}{ Statistics } \\
\cline { 3 - 6 } & Tolerance & VIF \\
\hline $\begin{array}{c}\text { 1. Cell Phone } \\
\text { addiction } \\
\text { 2. Web } \\
\text { browsing } \\
\text { addiction }\end{array}$ & .085 & 1.578 & .118 & .160 & .774 & .323 \\
\hline
\end{tabular}

a. Predictors: (Constant), Watsapp/messaging apps addiction, Social networking apps addiction,

Online gaming addiction

b. Dependent Variable: Phubbing

The determinants which are being excluded from the final regression model are being illustrated in Table 7. It shows that cell phone addiction $(\mathrm{t}=1.578, \mathrm{p}>.005)$ and web browsing addiction $(\mathrm{t}=.724, \mathrm{p}>.005)$ plays no significant role in affecting phubbing behavior of Generation Y. Finally the unstandardized coefficients (B) obtained in Table 6 are used to formulate the regression equation which is as follows:

$Y=.008+.380 X^{1}+.254 X^{2}+.373 X^{3}$

$\mathrm{Y}=$ Phubbing Behavior

$\mathrm{X}^{1}=$ Watsapp/Messaging addiction

$\mathrm{X}^{2}=$ Online gaming addiction

$\mathrm{X}^{3}=$ Social networking addiction

\section{CONCLUSION AND SUGGESTIONS}

In this contemporary world, where science and technology has given birth to the generation of a new era, human well-being and relationships are majorly affected by the use of mobile phones. Cell phone addiction has led to bring changes in the day to day routine of everyone's life and has created imbalances. The study reveals that the first thing people do while waking up in the morning and at the time of sleep is to continuous checking the phone. Further, this leads to many health issues like stress, depression, mental problems etc. The present study adds significant contribution to the existing literature on phubbing behavior by identifying the key determinants affecting phubbing behavior of the millennial. 


\section{The Determinants of Phubbing Behaviour: a Millenials Perspective}

The study found that Watsapp/messaging addiction, Online Gaming addiction and Social networking addiction has a positive effect on the phubbing behavior. Watsapp/messaging addiction is found to be the most important determinant of phubbing behavior. This is because of the widespread adoption of increasing computing needs through a medium of variety of communication. Also, the disruptions in technology created by these messaging apps have led to the generation of a new era in the means of communication among the millennial. The study reveals that online gaming addiction is found to be a significant factor in predicting phubbing behavior of the millennial. The reason behind this is the hierarchical relationship of the online gaming addiction with social media, internet and phone. The latest smart phones are equipped with the adequate navigation system with latest coordination between the functional keys so as to provide a real time gaming experience to its users. Also, the smart phone manufacturing companies are paying a considerable attention towards the gaming concern of the users and are competing against others in terms of providing a user friendly interface for hassle free gaming experience. The type of online gaming addiction affecting phubbing behavior includes PUB G, Counter Strike (CS), Need for Speed (NFS), Candy Crush and others. The present study also stated that social networking addiction leads to the phubbing behavior among Generation Y. Due to the rapid advancement in technology, people tends to communicate virtually rather than maintaining the direct relationships. They prefer to interact with their friends and relatives through mobile phone and not personally. The social networking sites such as Facebook, Twitter, Instagram, LinkedIn and others are gaining popularity these days because of its wider reach and accessibility. Also, these days the study and course material are also being shared between the students through various e-learning portals. Further, it has been found that Cell phone addiction and Web browsing addiction has no significant influence on the phubbing behavior the millennial. This is because of the availability of different types of apps related to diverse area of interests. The use of smart phones has become an integral part of everyone's life as a significant portion of the world's population use smart phones to conduct their everyday lives and simply cannot live without it. The usage of smart phones has the potential to hamper all types of interpersonal settings, including romantic relationships and discomfort among the partners. Also, as people become more and more reliant on their Smartphone, social exclusion has perhaps become a pervasive feature of everyday social interaction. The technology is always a double weapon and when it comes to affect human well-being than it should be used wisely. The need of the hour is to make human smart rather than making the phones smart. Therefore, it is suggested that the millennial should understand the main purpose of smart phones in our life and not to consider it as an addiction.

\section{REFERENCES}

1. Bayless, M. L., Clipson, T. W., \& Wilson, S. (2013). "Faculty perceptions and policies of students' use of personal technology in the classroom".

2. Campbell, S. W. (2006). "Perceptions of mobile phones in college classrooms: Ringing, cheating, and classroom policies”. Communication education, 55(3), pp. 280-294.
3. End, C. M., Worthman, S., Mathews, M. B., \& Wetterau, K. (2009) "Costly cell phones: The impact of cell phone rings on academic performance". Teaching of Psychology, 37(1), pp.55-57.

4. Fincham, F. D., \& Beach, S. R. (2010). "Marriage in the new millennium: A decade in review". Journal of Marriage and Family, 72(3), pp. 630-649.

5. Furman, W., Simon, V. A., Shaffer, L., \& Bouchey, H. A. (2002) "Adolescents' working models and styles for relationships with parents, friends, and romantic partners". Child development, 73(1), pp. 241-255.

6. Gilroy, M. (2004). "Invasion of the classroom cell phones". The Education Digest, 69(6), pp. 56.

7. Gottman, J. M., \& Notarius, C. I. (2002). "Marital research in the 20th century and a research agenda for the 21 st century". Family process, 41(2), pp. 159-197.

8. Griffiths, M. (2000). "Internet addiction-time to be taken seriously?" Addiction research, 8(5), pp. 413-418.

9. Harwood, J., Dooley, J. J., Scott, A. J., \& Joiner, R. (2014) "Constantly connected-The effects of smart-devices on mental health". Computers in Human Behavior, 34, pp. 267-272.

10. Howe, N., \& Strauss, W. (2000). "Millennials rising: The next great generation". Vintage.

11. Karadağ, E., Tosuntaş, Ş. B., Erzen, E., Duru, P., Bostan, N., Şahin, B. M., \& Babadağ, B. (2015). "Determinants of phubbing, which is the sum of many virtual addictions: A structural equation model. Journal of behavioral addictions", 4(2), pp. 60-74.

12. LaRose, R., Lin, C. A., \& Eastin, M. S. (2003). "Unregulated Internet usage: Addiction, habit, or deficient self-regulation?" Media Psychology, 5(3), pp. 225-253.

13. LiveMint, J. D. (2018). Jan 25.

14. Morey, J. N., Gentzler, A. L., Creasy, B., Oberhauser, A. M., \& Westerman, D. (2013). "Young adults' use of communication technology within their romantic relationships and associations with attachment style". Computers in Human Behavior, 29(4), pp 1771-1778

15. O'Bannon, B. W., \& Thomas, K. M. (2015). "Mobile phones in the classroom: Preservice teachers answer the call". Computers \& Education, 85, pp. 110-122.

16. Patel, S. N., Kientz, J. A., Hayes, G. R., Bhat, S., \& Abowd, G. D. (2006, September). "Farther than you may think: An empirical investigation of the proximity of users to their mobile phones". In International Conference on Ubiquitous Computing pp. 123-140. Springer, Berlin Heidelberg.

17. Sbarra, D. A., Briskin, J. L., \& Slatcher, R. B. (2019). "Smartphones and Close Relationships: The Case for an Evolutionary Mismatch". Perspectives on Psychological Science, 1745691619826535.

18. Shotton, M. A. (1991). "The costs and benefits of 'computer addiction"'. Behavior \& Information Technology, 10(3), pp. 219-230.

19. Tavakol, M., \& Dennick, R. (2011). "Making sense of Cronbach's alpha”. International journal of medical education, 2, 53.

20. Ugur, N. G., \& Koc, T. (2015). "Time for digital detox: Misuse of mobile technology and phubbing". Procedia-Social and Behavioral Sciences, 195, pp. 1022-1031.

21. Walsh, S. P., White, K. M., Cox, S., \& Young, R. M. (2011). "Keeping in constant touch: The predictors of young Australians' mobile phone involvement". Computers in Human behavior, 27(1), pp. 333-342.

22. Whitlow, M. L., Drake, E., Tullmann, D., Hoke, G., \& Barth, D. (2014). "Bringing technology to the bedside: using smartphones to improve interprofessional communication". CIN: Computers, Informatics, Nursing, 32(7), pp. 305-311.

23. Wickersham, A., Salehi, H., Pennathur, P., Linson, E., \& Are, C. A Kamath (2015). "Smartphones in the Improvement of Inter-Professional Communication.” Journal of Hospital Medicine, 10. 


\section{AUTHORS PROFILE}

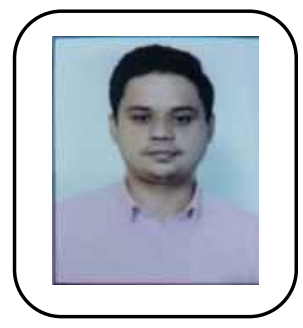

Dr. Saurabh Verma is a certified IP professional from WIPO. He is presently working as an Assistant Professor, Department of Management Studies (DoMS) at National Institute of Technology (NIT), Silchar, Assam (India). He has achieved his Doctoral degree in Consumer Psychology from National Institute of Technology (NIT), Kurukshetra, Haryana (India). He has worked on the issues of counterfeiting in India. His research area includes Intellectual Property Rights; Consumer Psychology \& Brand Management. He has published a number of Research Articles/Papers in the journals of National and International repute.

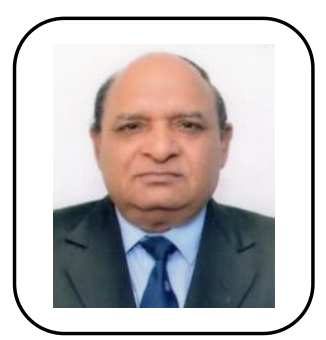

Dr. Rajender Kumar is a Professor in the Department of Business Administration, National Institute of Technology (NIT), Kurukshetra, Haryana (India). He has served as a Professor and Head, Department of Humanities and Social Sciences and Department of Business Administration in the same institute for a period of 11 years. He completed his Ph.D. in 1984 from IIT, Roorkee. He has published 40 Research Papers in National/ International journals. He received the best paper award from the Institution of Engineers for the paper "Automation- its Socio-Economic impact - A case study of India in 1990. He was also conferred Research Fellow by American Biographical Institute, USA (1990).

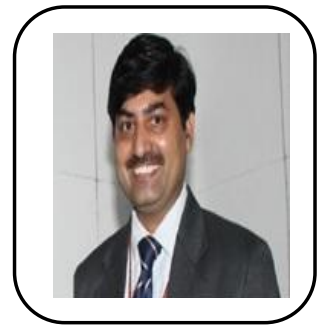

Dr. Sunil Kumar Yadav is an academician with a rich experience of 16 years which includes 07 years of core corporate work spanning across various pharmaceutical companies at managerial positions. He did his $\mathrm{PhD}$. in the domain of Intellectual Property Rights from National Institute of Technology, Kurukshetra (Haryana) India. $\mathrm{He}$ is presently working as Assistant Professor at Rukmini Devi Institute of Advanced Studies, Delhi. His current areas of Research are Intellectual Property Rights its implementation and implications on Indian firms. He has published a number of research papers in Journal of National and International repute. 